\title{
GEOMETRIC AND STATIC ANALYSIS OF THE HISTORICAL TRUSSES IN ROMAN CATHOLIC CHURCH OF THE HOLY KOZMA AND DAMIAN IN THE ABRAMOVÁ VILLAGE
}

\author{
Peter KRUŠINSKÝ ${ }^{1,{ }^{*}, \text { Eva CAPKOVÁ }}{ }^{2}$, Jozef GOCÁL ${ }^{3}$, Michaela HOLEŠOVÁ ${ }^{4}$ \\ ${ }^{1}$ Department of Building Engineering and Urban Planning, Faculty of Civil Engineering, University of \\ Žilina, Univerzitná 1, 01026 Žilina, Slovakia. \\ 2 Department of Mediamatics and Cultural Heritage, Faculty of Humanities, University of Žilina, \\ Univerzitná 1, 01026 Žilina, Slovakia. \\ ${ }^{3}$ Department of Structures and Bridges, Faculty of Civil Engineering, University of Žilina, Univerzitná \\ 1, 01026 Žilina, Slovakia. \\ ${ }^{4}$ Department of Mathematics, Faculty of Humanities, University of Žilina, Univerzitná 1, 01026 Žilina, \\ Slovakia. \\ corresponding author: krusop@fstav.uniza.sk.
}

\begin{abstract}
The truss of the Roman Catholic Church of the holy Kozma and Damian was managed to date to the year 1470/71d. It represents one of the few well-preserved medieval structures in this region. The form of roofs is a typical for rafter collar-beam construction without stiffening frame. The geometrical analysis of the main roofs trusses is based on logical dependencies and a description of a process in the truss design, pointing to evaluative relations resulting especially from the Pythagorean Geometry. Consequently, a spatial numerical model of the roof structure was developed in order to perform a static analysis of the roof structure in accordance with present standards. Due to the fact that during the diagnostic survey there were noted some missing structural elements in the roof construction (angle braces), in further analysis, an attention was paid to the importance of the selected structural elements and their role in the construction of the truss itself.
\end{abstract}

\section{Keywords:}

Historical trusses;

Geometric analysis;

Static analysis.

\section{Introduction}

The Roman-Catholic Church of the Holy Kozma and Damian in Abramová is located in the periphery of the village of Abramová, in the middle of the cemetery. The Church was built in $1380 \mathrm{~d}$ and is the construction with one nave with the rectangular floor plan. The sanctuary is on the north side with a separate room for the sacristy and the tower, [2] Fig. 1.

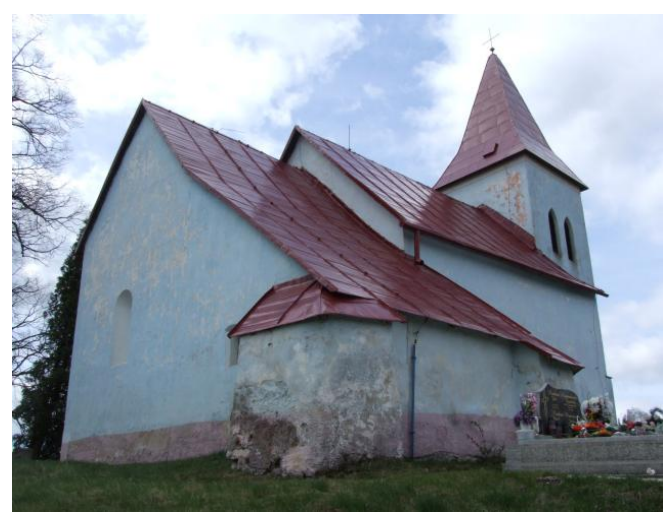

Fig.1: The Roman-Catholic Church of the Holy Kozma and Damian in Abramova village. 
The truss above the nave has a rafter collar-beam construction without longitudinal stiffening frame truss. It consists of ten constructional same trusses, which are made up of a pair of rafters. In the top the rafters they are joined by top pin. The collar-beam and the rafters are joined together by a dovetail joints. All of the original carpentry joints are secured with wooden dowels; secondary elements are fixed with the original ones by metal-tipped nails, [2] Fig. 2.

The truss above the sanctuary has a simply rafter collar-beam construction without longitudinal stiffening frame truss and braces. The authentic elements from first truss are wall beams, transverse beams and two trusses (1380d). Between collar-beam and the rafters for joining are used dovetail joints. Top of trusses was joint with vertex tenon, [2] Fig. 3.

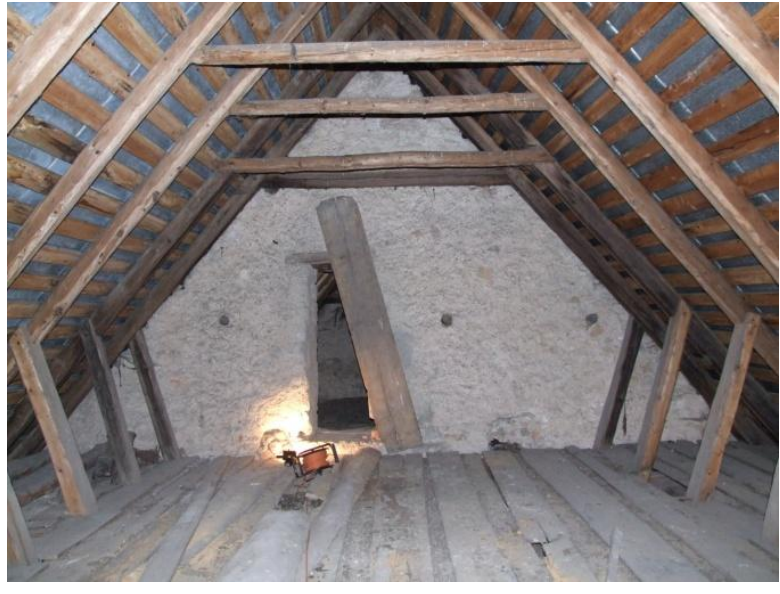

Fig. 2: The truss above the nave.

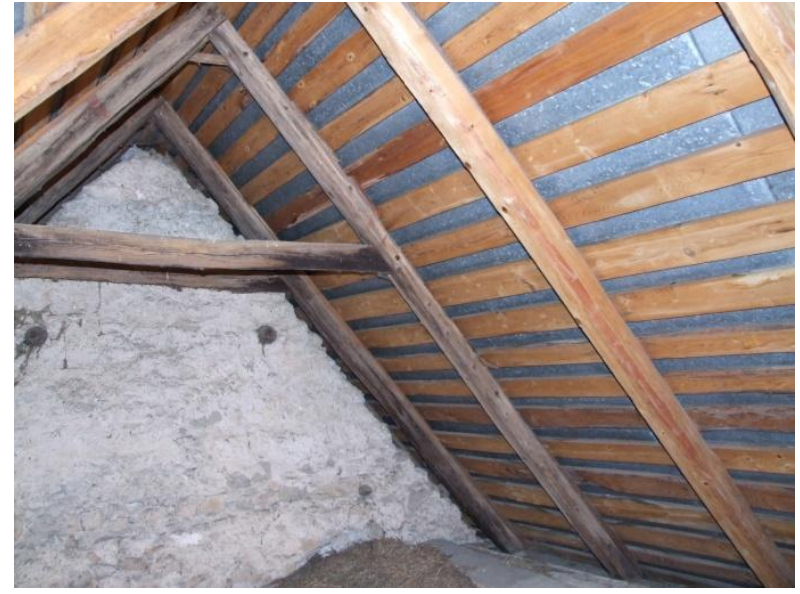

Fig. 3: The truss above the presbytery.

\section{Geometric analysis of the trusses}

All geometric constructions, not only geometric constructions in the truss, but geometric constructions in the floor plan as well, are based on the basic square ABCD, which side has a length a equals to half of the truss above the nave. The floor plan of the truss above the nave is square shaped and its dimensions are twice the square $A B C D$, i.e. the width of the truss above the nave has a length of $2 a$. The floor plan above the sanctuary is rectangular shaped and a length of the rectangle is equal to a length of the diagonal of the basic square, i.e. the width of the truss above the sanctuary has the length equals to $\sqrt{2} \mathrm{a}$, Fig. 4 .

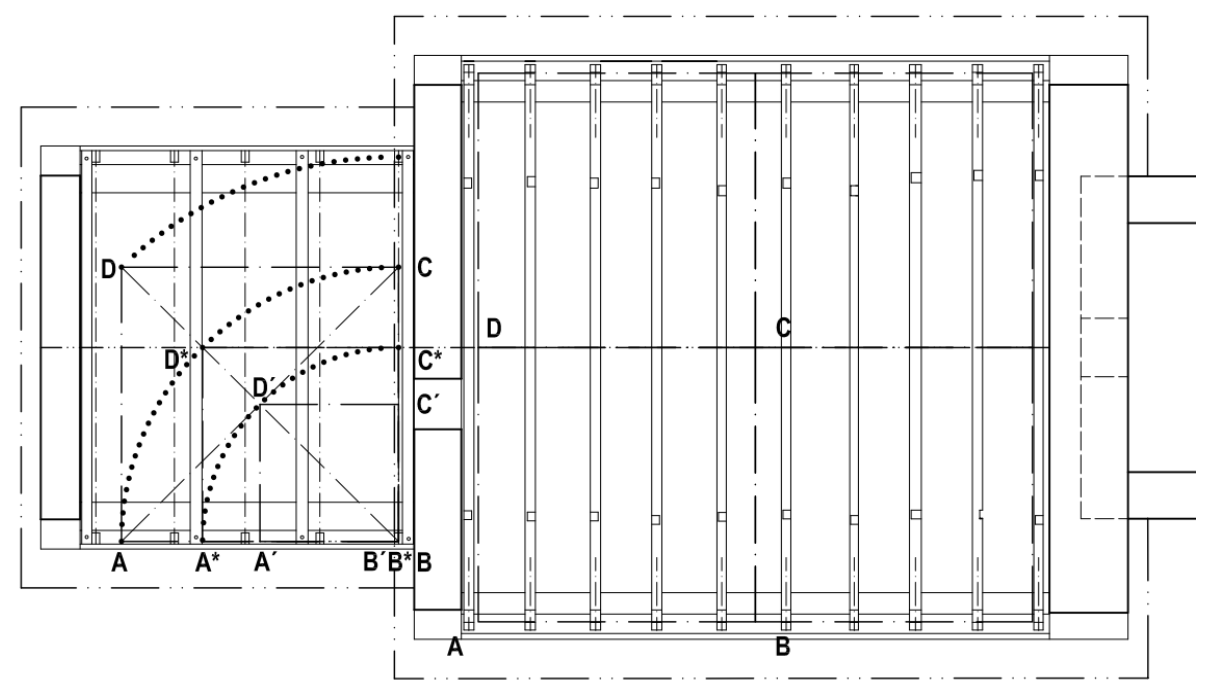

Fig. 4: Definition of the basic square ABCD. 
The roof above the nave has a simple rafter collar-beam construction with the raking braces. The relationship between the width and height of the truss can we quantify by the ratio 14: $8=7: 4$, but we assume that the height of the truss was obtained by adding the seventh to the half of the width, thus there has been used the principle $n$ plus one, where $n$ is equal 7 . The width of the roof above the nave has a length of $2 a$ and the height of the truss has a length of $(a+a / 7)$. The numerically expressed relationship between all three dimensions of the truss above the nave is width : length : height $=7: 7: 4$. The collar-beam is located in two thirds of the height of the truss and the ending of the raking brace on the rafter is located in one-third of the height of the truss. The ending of raking braces on the tie beam is located in a fifth of the overall width of truss, Fig. 5.

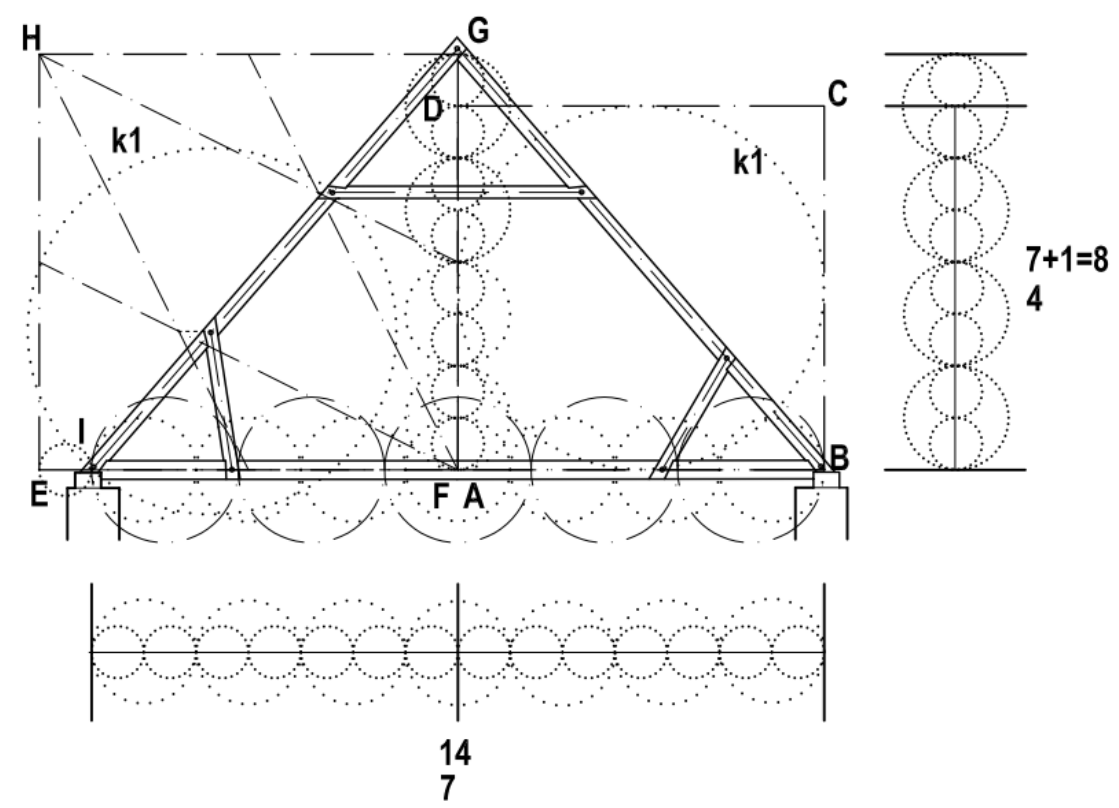

Fig. 5: Geometric construction of the truss above the nave.

The truss above the sanctuary still has a simpler design than the truss above the nave; it is a collar beam construction without ranking braces. As we already mentioned in the description of the floor plan of the truss above the nave, there is a relationship between the width of the truss above the nave and the width of the truss above the sanctuary, that we can quantify: $\sqrt{2}: 1=1: \frac{\sqrt{2}}{2}$. Analogically as the height above the nave was constructed the height of the truss above the sanctuary by, now to the half of the width of the roof was added to its ninth. The relationship between the width and the height of the truss quantified over the sanctuary is: $18: 10=8: 5$. The collar beam is located on the king post so that it was at a height of, which is the width of the roof again in a relationship $1: \sqrt{2}$, Fig. 6.

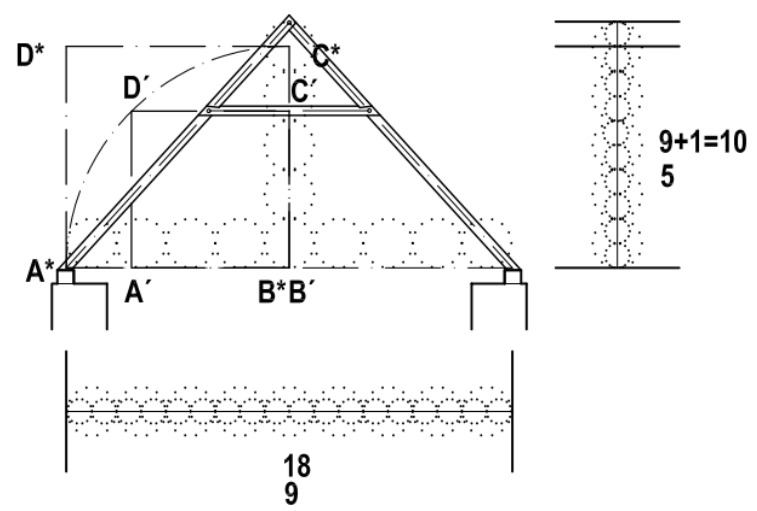

Fig. 6: Geometric construction truss above the presbytery. 


\section{Static analysis of the trusses}

Numerical models of the roof structure were developed in the finite element analysis (FEA) software SCIA Engineer [4]. Because of a very simple construction of the roof structure, consisting only of uniform cross-trusses, the planar numerical models of the individual trusses were created for their static analysis. The geometry of numerical models is related to the geometrical analyses of the trusses presented hereinbefore. The basic geometric parameters of the numerical models are shown in Fig. 7. The cross sections of members are designated in the form bxh [mm], where "b" is the width and " $\mathrm{h}$ " is the height of the cross section in millimetres. In the both models, there is also taken into account the weakening of cross sections by carpentry joints (Fig. 8). Mechanical properties of the wood are taken into account applying the strength class of C24 according to [5]. All the member connections are modelled as hinge joints with axial rigid connection and with capability of initial slip of $1 \mathrm{~mm}$ in the axial direction of member in order to consider theoretical influence of gaps, cracks or other geometry imperfections, occurring in historical carpentry joints.
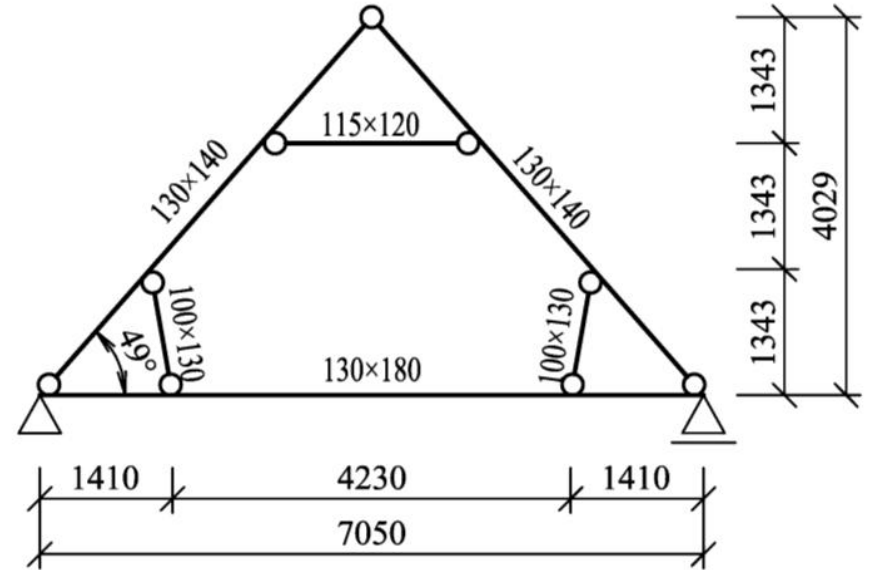

a) Truss above the nave

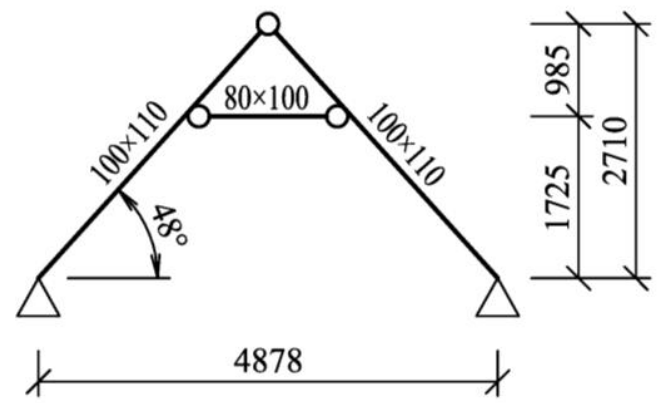

b) Truss above the sanctuary

Fig. 7: Numerical model of the cross trusses of roof structure.

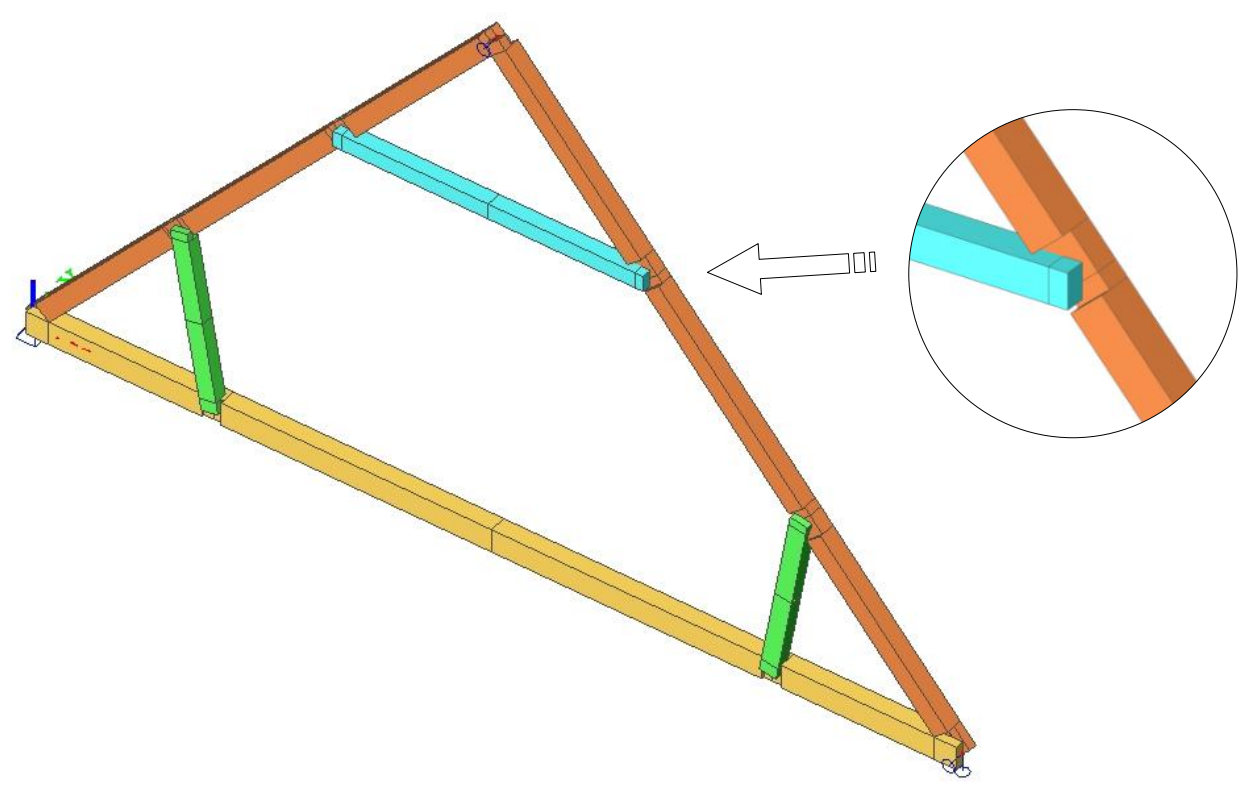

Fig. 8: Visualization of the numerical model of the cross truss above the nave. 
The roof structures were loaded according to European standards [6, 7, 8, 9] by permanent load (self-weight and weight of roofing) and variable load (wind actions and snow load). The uniformly distributed loads on the rafters are considered in proportion to their axial distances, which are $825 \mathrm{~mm}$ above the nave and $1000 \mathrm{~mm}$ above the sanctuary. The combinations of load cases were generated according to the standard STN EN 1990 [6].

The results of numerical analysis of the both trusses are presented by the values of normal and shear stresses and displacements in the major structural members of trusses, calculated for the decisive load combinations. The envelopes of maximum tensile (+) and compression (-) stresses in the major truss members are presented in Fig. 9. The presented values do not include possible buckling effects, which are negligible because of low share of compression forces. The envelopes of maximum shear stresses are presented in Fig. 10. The envelopes of deformations are presented in Fig. 11.

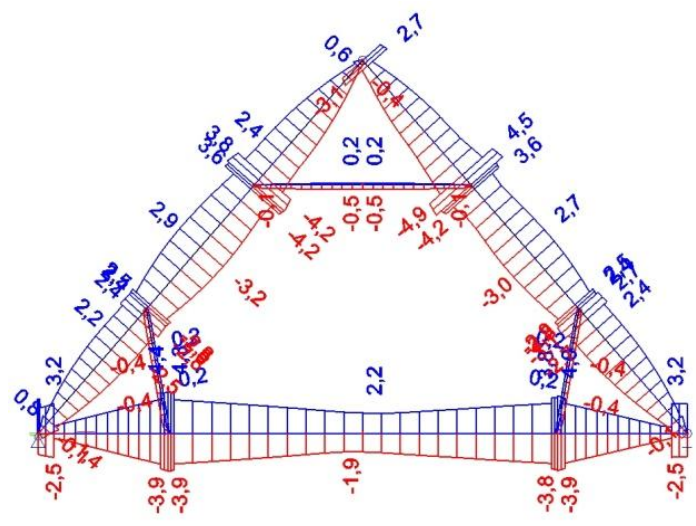

a) Truss above the nave

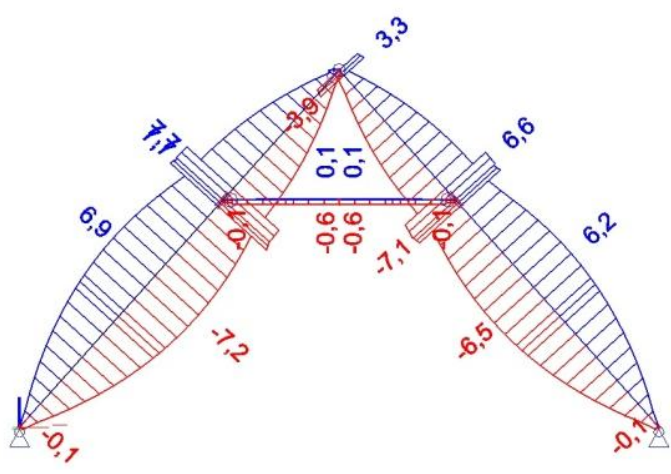

b) Truss above the sanctuary

Fig. 9: Normal stresses (MPa) in the main truss members.

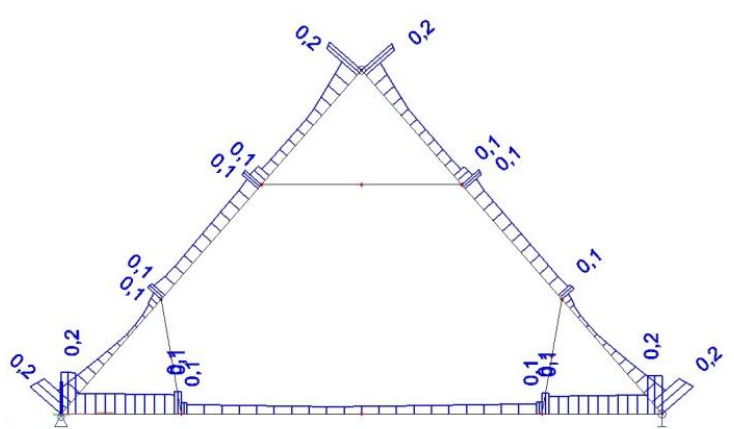

a) Truss above the nave

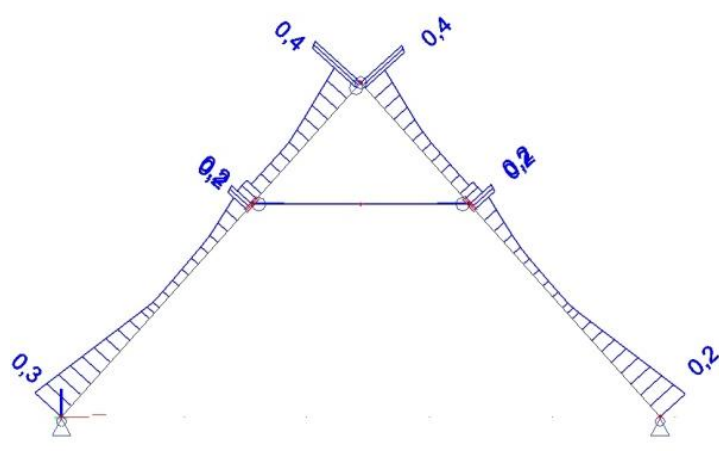

b) Truss above the sanctuary

Fig. 10: Shear stresses (MPa) in the main truss members.

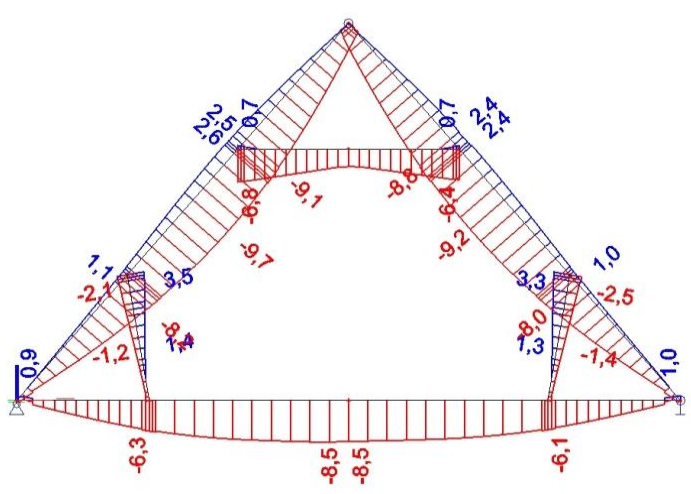

a) Truss above the nave

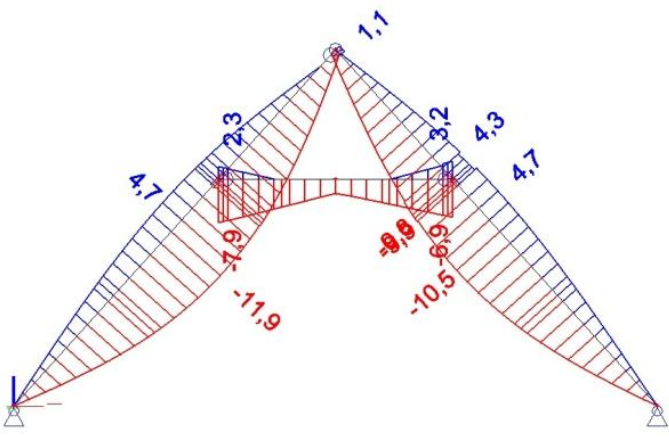

b) Truss above the sanctuary

Fig. 11: Vertical deformations $(\mathrm{mm})$ in the major truss members. 
Based on the results of numerical analysis it can be stated out that in the both investigated truss members the normal stresses do not exceed the design values of bending and compression strength equal to $16.60 \mathrm{MPa}$ and 14.53 $\mathrm{MPa}$, respectively, determined according to STN EN 1995-1-1 [10], assuming the timber strength class $\mathrm{C} 24$, modification factor $\mathrm{k}_{\bmod }=0.9$ and partial safety factor $\square_{M}=1.3$. The shear stresses do not exceed the design value of shear strength equal to $2.77 \mathrm{MPa}$, as well. Quite the opposite, it can be stated that the both trusses are much over dimensioned even from the viewpoint of the current European standards.

\section{Conclusions}

The research results point to a rational approach to the design of roof trusses used geometry and arithmetic. Unlike now, an approach to the planning of the structure service life was significantly different, looked through a number of other generations. For the design they used the musical ratios and irrational proportions, which were considered to be perfect. The results showed that the roof structure safely satisfy (with reserve about $42 \%$ in truss above nave and in truss above sanctuary $18,2 \%)$ the reliability conditions defined by current European standards for structural design, both in terms of the ultimate limit states and serviceability limit states. The reserve extends the service life in relation to the potential long-term damage to the life of roof truss constructions and enables their rehabilitation.

\section{Acknowledgement}

This paper presents results of works supported by the Scientific Grant Agency of the Slovak Republic under the project No. 1/1296/12.

\section{References}

[1] STRUHÁR, A.: Geometric harmony of historical architecture in Slovakia. Bratislava. Pallas, 1977.

[2] SUCHÝ, L. - KRUŠINSKÝ, P. - BABJAKOVÁ, Z. - ĎURIAN, K.: Historic trusses of sacral buildings of Turiec. University of Žilina, 2008, ISBN 978-80-965547-9-7.

[3] The Complete Pythagoras. Internet version of Kenneth Sylvan Guthrie's Pythagorean Sourcebook and Library (1922), ed. Patrick Rousell. http://www.completepythagoras.net.

[4] SciaEngineer 2010. Software for structural analysis. http://nemetschek-scia.com/sk.

[5] STN EN 338 Structural timber. Strength classes. SÚTN, Bratislava 2004.

[6] STN EN 1990 Eurocode. Basis of structural design. SÚTN, Bratislava 2009.

[7] STN EN 1991-1-1 Eurocode 1. Actions on structures. Part 1-1: General actions. Densities, selfweight, imposed loads for buildings. SÚTN, Bratislava 2007.

[8] STN EN 1991-1-3 Eurocode 1. Actions on structures. Part 1-3: General actions - Snow loads. SÚTN, Bratislava 2007.

[9] STN EN 1991-1-4 Eurocode 1. Actions on structures. Part 1-4: General actions - Wind actions. SÚTN, Bratislava 2007.

[10]STN EN 1995-1-1 + A1 Eurocode 5. Design of timber structures. Part 1-1: General. Common rules and rules for buildings. SÚTN, Bratislava 2008.

[11]GOCÁL, J. - KRUŠINSKÝ, P. - CAPKOVÁ, E. - KEKELIAK, M.: Geometric and static analysis of the historical truss in village Belá Dulice. In: Advanced materials research. ISSN 1022-6680. Vol. 969 (2014), s. 199-207. doi:10.4028/www.scientific.net/AMR.969.199. 